\title{
CURRENT STABILITY MODELLING OF AN INCIPIENT SAN ANDRÉS GIANT LANDSLIDE ON EL HIERRO ISLAND, CANARIES, SPAIN - FIRST ATTEMPT USING LIMITED INPUT DATA
}

\author{
Jan BLAHŮT 1) *, Filip OLEJÁR ${ }^{2,3)}$, Josef ROTT ${ }^{2)}$ and Matěj PETRUŽÁLEK ${ }^{4)}$ \\ 1) Institute of Rock Structure and Mechanics, The Czech Academy of Sciences, Department of Engineering Geology, \\ V Holešovičkách 94/41, 18209 Prague, Czechia \\ ${ }^{2)}$ Institute of Hydrogeology, Engineering Geology and Applied Geophysics, Charles University in Prague, \\ Faculty of Sciences, Albertov 6, 12843 Prague, Czechia \\ 3) SUDOP Praha, JSC, Olšanská 1 a, 13080 Prague, Czechia \\ 4) Institute of Geology, The Czech Academy of Sciences, Department of Physical Properties of Rocks, Puškinovo náměstí 447/9, 16000, \\ Prague, Czechia \\ *Corresponding author 's e-mail: blahut@irsm.cas.cz
}

\begin{tabular}{l} 
ARTICLE INFO \\
\hline Article history: \\
Received 8 November 2019 \\
Accepted 17 January 2020 \\
Available online 4 February 2020 \\
\hline
\end{tabular}

\section{Keywords:}

Stability modelling,

Limit Equilibrium Analysis,

San Andrés Landslide,

El Hierro, Seismic loading,

Sea level change

\begin{abstract}
This paper presents first results from stability modelling of a deep-seated San Andrés Landslide located on the El Hierro Island, Canaries. It combines information from own surficial field surveys, geotechnical testing, literature and analogies from other parts of the island and Canary Islands in general. Despite using limited data a slope profile for modelling has been defined and several models have been calculated. These include variations in the rock properties, influence of seismic loading and differences in sea level. This first attempt shows that San Andrés Landslide is currently stable however; it might be reactivated as a result of an earthquake with minimum VII intensity. Even in seismically calm periods a creep might be induced by the unconsolidated sea sediments located at the toe of the landslide. However, more detailed information about the internal structure of the landslide and rock properties is needed for thorough conclusions.
\end{abstract}

\section{INTRODUCTION}

Landslides from volcano collapses represent important geological hazard (van Wyk de Vries and Francis, 1997) and can affect volcanic edifices across all tectonic settings and involve rapid redistribution of mass (Watt, 2019). The volume of these collapses is fully comparable with largest rock avalanches and landslides on Earth and Mars (Blahůt et al., 2019).

The instability of volcanic slopes is a result of large number of factors including high relief, steep slopes, presence of unconsolidated material, intrusion of dikes, debuttressing effect of marine erosion and changes in sea levels on coastal volcanoes, influence of volcanic fluids, gases and explosions, increased pore pressures from hydrothermal water accompanying magmatic intrusions, or gravitational spreading (Voight et al., 1983; Ellsworth and Voight, 1995; Iverson, 1995; Siebert, 2002)

Slope stability modelling is currently a routine operation. However, modelling of a volcano edifice collapse is still not done frequently. Reid et al. (2001) used three-dimensional slope stability method to assess flank stability of Mount Rainier. Cecchi et al. (2005) used analogue modelling to simulate surface deformation and internal structure of spreading flanks. Apuani et al. (2005) performed stability analysis of
Stromboli island volcano using limit equilibrium methods (LEM) and finite difference modelling focusing mainly on the subaerial part of the volcano. Moon et al. (2009) did slope stability modelling of a White Island Volcano, New Zealand also applying 2D limit equilibrium analysis, different water table ranges and earthquake accelerations. Borselli et al. (2011) made several collapse scenarios of Volcán de Colima, Mexico using LEM analysis and debris avalanche runout modelling. Del Potro et al. (2013) performed a parameter sensitivity analysis on different factors contributing to the instability of Teide volcano in Tenerife using finite element and LEM models. Ferrer et al. (2014) performed stability analysis on La Palma and Tenerife islands using PLAXIS software. Harnett et al. (2018) used discrete element approach to model lava dome emplacement and collapse. Dondin et al. (2017) assessed likelihood of future collapse of Kick-'em-Jenny submarine volcano near Grenada and based on LEM analysis concluded that all flanks of the volcano are currently stable. The reason of the limited number of examples is mostly related to problems with limited geotechnical information on the rock properties and restricted knowledge of the sub-surface and/or sub-marine geological structure of the volcano. 


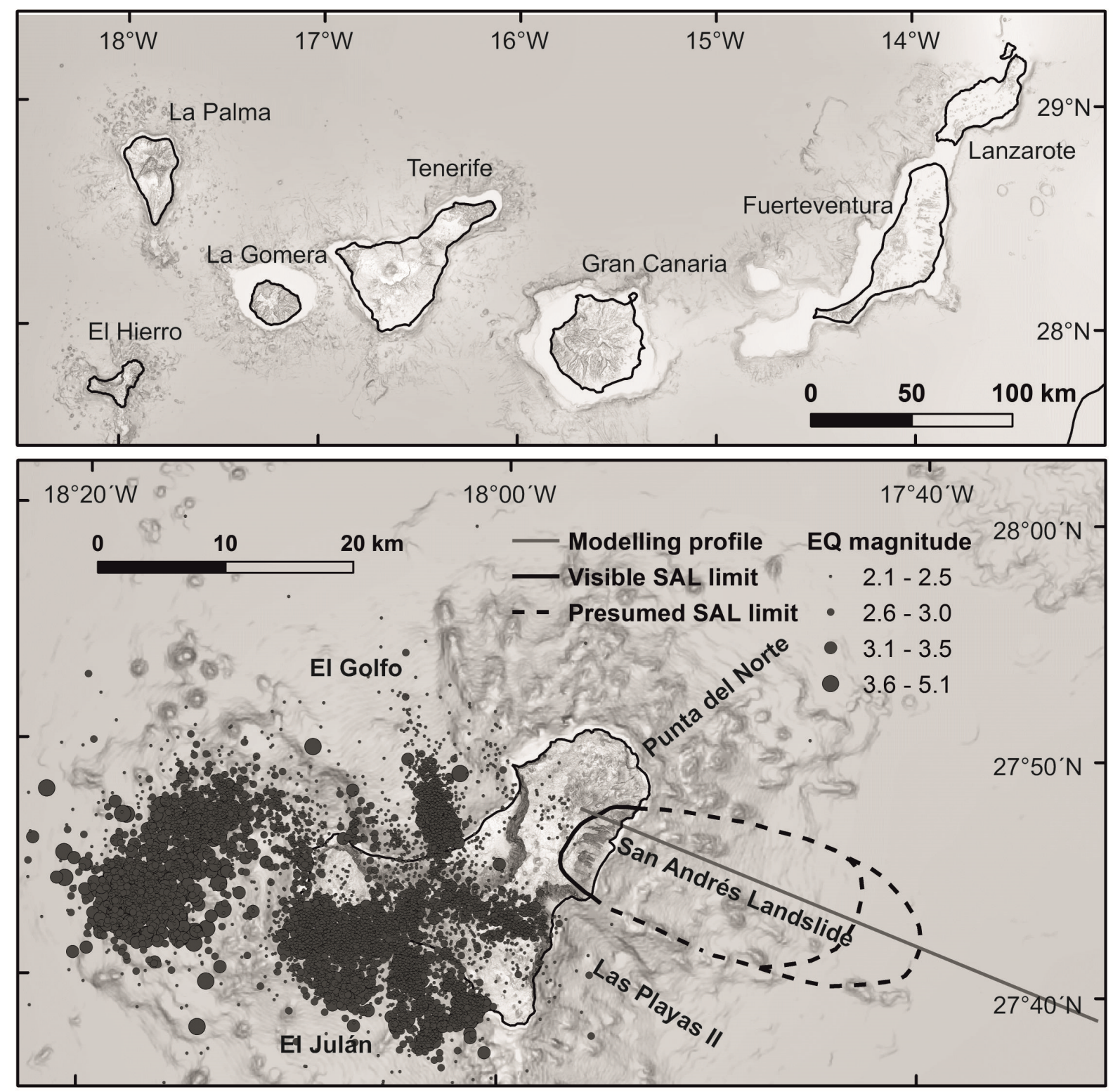

Fig. 1 Location of the study area within Canary Islands (up) and location of the modelling profile of the San Andrés Landslide (SAL) on El Hierro (down). Epicentres of earthquakes for the seismic period 7/201112/2014 are shown - only records with $\mathrm{M}>2.0$ are visible (IGN, 2018).

The aim of this work is to assess for first time the current stability of the San Andrés Landslide (Klimeš et al., 2016) on the El Hierro Island in the Canaries, Spain using limited data. For that purpose, several scenarios were also made using different sea levels and peak ground accelerations (PGA) to evaluate possible landslide hazard in the future. Other external effects like shallow magma intrusions or overpressure (Iverson, 1995; Donnadieu et al., 2001; Apuani et al., 2005, 2009) were not considered in this paper due to model limitations and incomplete information.

\section{STUDY AREA}

El Hierro is the youngest, smallest and westernmost island of the Canary Archipelago. Its volcanic edifice emerges from approximately $3.700 \mathrm{~m}$ deep ocean floor and reaches approx. $1.500 \mathrm{~m}$ (Schmincke and Sumita, 2010). The oldest rocks on the island belong to Tiñor Unit, which has maximum age of 1.12 Ma (Guillou et al., 1996) and forms the northern and north-eastern parts of the island. This unit is thought to have developed rapidly until around the time of the Tiñor debris avalanche at $0.88 \mathrm{Ma}$ (Carracedo et al., 2001). The rocks of the El Golfo-Las Playas Unit, with a maximum age of $0.55 \mathrm{Ma}$ (Guillou et al., 1996) overlaid the Tiñor Unit and infilled the scarp area of the Tiñor debris avalanche (Carracedo et al., 2001). The youngest rocks are represented by the Rift Series which has a maximum age of $0.16 \mathrm{Ma}$ (Guillou et al., 1996). Over the past 33000 years onshore eruptions reoccur approximately once every 1000 years (Becerril et al., 2016a). The most recent, ongoing, phase of volcanism began around $2.5 \mathrm{ka}$ (Carracedo et al., 2001). Latterly a period of intense seismic activity begun in July 2011 (López et al., 2012) and lasted until 2014 (Benito-Saz et al., 2017). Additionally, an offshore eruption commenced on 10 October 2011 and ended in March 2012 (Meletlidis et al., 2015). 


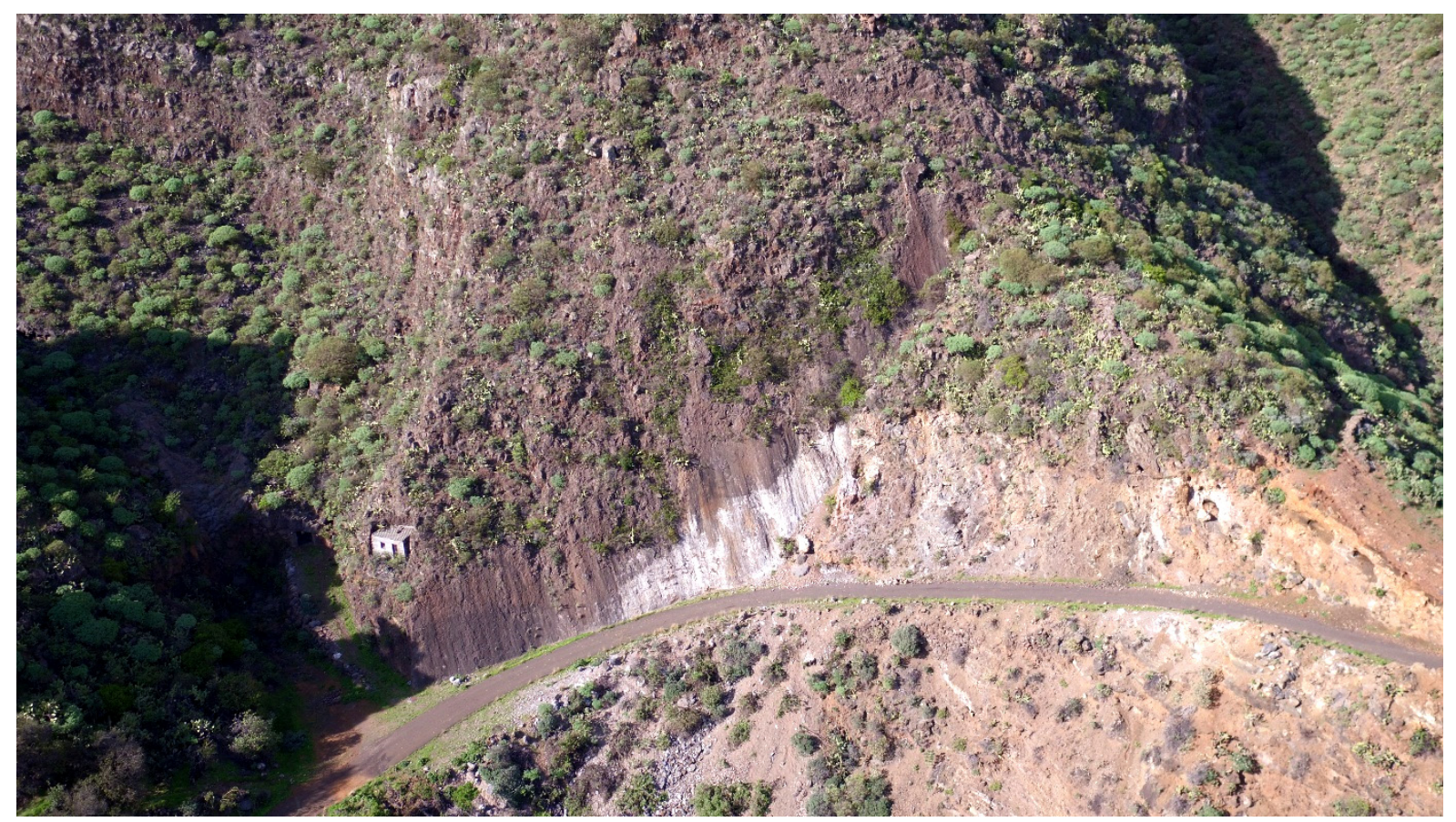

Fig. 2 Aerial view of the prominent San Andrés Fault, which delimits the detachment plane of the San Andrés Landslide $\left(27^{\circ} 47.32^{\prime} \mathrm{N}, 17^{\circ} 55.31^{\prime} \mathrm{W}\right)$. Collapse accumulations are visible on lower right, while lava flows outcrop in the upper part of the photo. Photo Jan Blahůt.

For a more detailed description of the geology of the island, please refer to Blahůt et al. (2018a).

The characteristic three-point star morphology of El Hierro is a result of a number of enormous flank collapses (Fig. 1). Until now, seven debris avalanches have been identified: Tiñor $(<880 \mathrm{ka})$, Las Playas I (545-176 ka), Las Playas II (176-145 ka), El Julan (> $158 \mathrm{ka})$, El Golfo A (176-133 ka), El Golfo B (87$39 \mathrm{ka}$ ), and Punta del Norte (unknown age) (Masson, 1996; Urgeles et al., 1996, 1997; Carracedo et al., 1999, 2001; Masson et al., 2002; Longpré et al., 2011; Becerril et al., 2016b; Carracedo and Troll, 2016; León et al., 2017; Blahůt et al., 2018b). In addition, a large slump, sensu Moscardelli and Wood (2008), or a deep-seated gravitational slope deformation, sensu Sorriso-Valvo et al. (1999) or Agliardi et al. (2001), is located on the eastern flank of the volcanic edifice (Klimeš et al., 2016). This feature, the San Andrés Landslide, is defined by a group of pronounced faults which represent landslide detachment planes. Similar features have been described from other volcanic islands including the Azores (Hildenbrand et al., 2012) and the Hawaiian Islands (Duffield, 1975). It has previously been proposed that the San Andrés Landslide is an anchored block associated with the debris avalanche Las Playas I (Day et al., 1997).

The San Andrés Landslide has developed in the rocks of the Tiñor Unit. This unit incorporates three distinct subunits: the basal subunit comprises relatively thin, $20-40 \mathrm{~cm}$, steeply dipping lava flows; the intermediate subunit, which forms the majority of the unit, comprises thicker, up to $4 \mathrm{~m}$, shallow dipping lava flows; the third subunit is formed by emission vents with well-preserved craters and associated lavas (Gómez Sainz de Aja et al., 2010). The broad arcuate and presumably listric fault system which defines the boundaries of the landslide mass to the northeast is terminated to the southwest by an escarpment associated with the debris avalanche at Las Playas. Geological evidence suggests that the landslide mass is moving progressively to the east and southeast (Troll and Carracedo, 2016) while creep, in the order of $0.5 \mathrm{~mm} /$ year, has recently been detected along its main detachment plane (Blahůt et al., 2017, 2018a). Furthermore, the landslide mass is dissected by a series of deeply entrenched gullies, with a relative relief of more than $200 \mathrm{~m}$, oriented northwest to southeast. The offshore part of the landslide exhibits a large number of ridges and blocks. Internal structure of the landslide is poorly known because there are neither seismic data nor deep boreholes, and therefore, all direct observations come from artificial galleries and deeply incised gullies. However, even these limited observations suggest that the basal detachment plane has a compound roto-translational character (Blahůt et al., 2020).

\section{DATA AND METHODS 3.1. AVAILABLE DATA}

There are only limited data available on the SE slope of the El Hierro Island, which might be used for the construction of the modelling profile and the stability modelling. For that reason, a combination of surficial surveys, own geotechnical testing, literature and analogies from other parts of the island and Canary Islands in general were used to construct the model. 


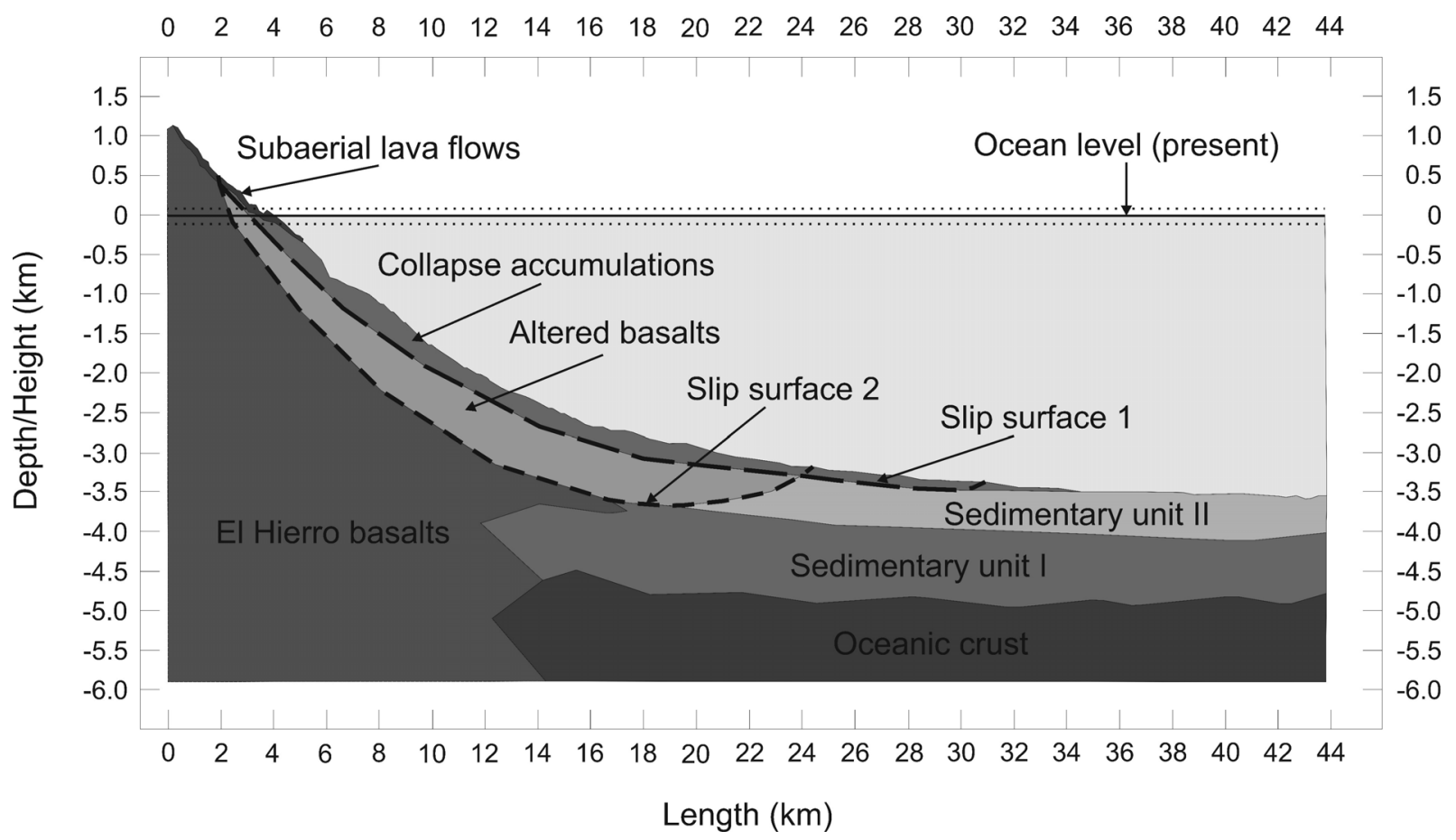

Fig. 3 Constructed modelling profile of the eastern flanks of El Hierro. The profile runs from WNW to ESE as shown on Figure 1.

Available data included LiDAR-derived digital terrain model (MDT05, 2015) combined with bathymetric data (IHM, 2016). Information inferred from a geological map 1:25 000 (Gómez Sainz de Aja et al., 2010) was coupled with geomorphological mapping (Klimeš et al., 2016) and information about geological evolution of the El Hierro Island (Carracedo et al., 1999, 2001; Troll and Carracedo, 2016). The groundwater level on El Hierro equals the sea level, for that reason the island has also many problems with supplying enough water for its inhabitants.

According to available seismic reflection data (Gee et al., 2001; Krastel et al., 2001; Masson et al., 2002) the lower part of the SE slopes is composed of chaotic debris avalanche deposits, which appear to be superimposed over deformed strata. However, other information about submarine structure was not available for this side of the island. For that purpose, it was worked with an analogy from NW part of El Hierro. León et al. (2017) in their work analysed the NW off-shore part of El Hierro with seismic profiles and they propose a geological model coupling Jurrasic oceanic crust and sedimentary sequence composed of three units (Urgeles et al. 1998). These units are wedge-shaped, increasing in thickness towards the flanks of the island (León et al., 2017).

Additional information was gathered from two sites, which were drilled around Gran Canaria island (Weaver et al., 1998). Borehole 954 is situated around $35 \mathrm{~km} \mathrm{~N}$ from Gran Canaria (around $240 \mathrm{~km}$ from El Hierro) and borehole 956 is located around $55 \mathrm{~km}$ SW from Gran Canaria (around $180 \mathrm{~km}$ from El Hierro). Despite the long distance from the study site, they can be used as a stratigraphical model thanks to similar evolution and repeating flank collapses. In both holes the upper layers are formed by mixed bioclastic clayey sediments with coarse debris (including tuffs and tefrites) reaching around $150 \mathrm{~m}$ depth. The lower parts of the holes are formed by alternating layers of sea sediments with nannofossils and thin layers of tuffs, basaltic breccia, slope debris and slump sediments.

The available information was supplemented with data from geotechnical testing. Two soil samples were taken from the detachment plane of the San Andrés Landslide and three rock samples (1 basaltic rock, 2 basanite lavas) were taken in the vicinity of the detachment plane. The soil samples were tested in the Soil Mechanics Laboratory of the Charles University in Prague (Faculty of Sciences) to obtain basic characteristics and shear strengths. The rock samples were tested in the Geological Institute of the Czech Academy of Sciences to obtain basic rock parameters, static and dynamic moduli and triaxial strengths.

\subsection{PROFILE CONSTRUCTION}

Modelling profile (Figs. 1, 3) was set on the eastern side of the El Hierro Island and has WNWESE direction. It is $43.84 \mathrm{~km}$ long starting at altitude of $1111 \mathrm{~m}$ a.s.l. going to depth of $3591 \mathrm{~m} \mathrm{b.s.1}$. It was derived from a joined DEM (MDT05, 2015; IHM, 2016), which has subaerial resolution of $5 \mathrm{~m}$ and submarine resolution of $1 / 16$ arc minutes (approx. $115 \mathrm{~m}$ ). At and altitude between 490 and $476 \mathrm{~m}$ a.s.1. lies the morphologically well pronounced giant landslide detachment/fault plane with an inclination of approx. $65^{\circ}$ called San Andrés Fault.

Totally 7 geotypes were distinguished in the model (Fig. 3). The submarine part was reconstructed from León et al. (2017) and Urgeles et al. (1998). The 
Table 1 Modelling parameters used in the analysis.

\begin{tabular}{|c|c|c|c|c|c|}
\hline $\begin{array}{l}\text { Geotype } \\
\text { number }\end{array}$ & Geotype & $\begin{array}{c}\text { Friction angle } \\
\varphi\left({ }^{\circ}\right) \\
\end{array}$ & $\begin{array}{l}\text { Cohesion } \\
c(\mathrm{Mpa})\end{array}$ & $\begin{array}{l}\text { Unit weight } \\
\rho\left(\mathrm{kN} / \mathrm{m}^{3}\right)\end{array}$ & Reference \\
\hline 1 & Oceanic crust & 45.5 & 44 & 28.84 & Cai et al. (2015) \\
\hline 2 & Sedimentary unit I & 16 & 0.001 & 26.29 & Stow (2009) \\
\hline 3 & Sedimentary unit II & 20.5 & 0.001 & 26.49 & $\begin{array}{l}\text { Stow (2009) } \\
\text { modified after Masson et al. (2002) }\end{array}$ \\
\hline 4 & Fresh basalt & 45.5 & 44 & 29.92 & Petružálek (2018) - own results \\
\hline $5 \mathrm{a}$ & Low altered basalt & 40 & 10 & 28.15 & Olejár (2018) - own results \\
\hline $5 \mathrm{~b}$ & High altered basalt & 38.5 & 4 & 27.66 & Olejár (2018) - own results \\
\hline 6 & $\begin{array}{l}\text { Collapse } \\
\text { accumulations }\end{array}$ & 38.5 & 0.003 & 19.13 & Olejár (2018) - own results \\
\hline 7 & Lava flows & 33.5 & 5.1 & 22.46 & Petružálek (2018) - own results \\
\hline
\end{tabular}

sedimentary units are deposited on the oceanic crust (Geotype 1). They are pre-volcanic sediments deposited since Cretaceous till present. However, missing detailed information of this side of the island (seismic profiles) does not allow to precisely estimate the depth of the sedimentary units. For that reason, only two sedimentary units were distinguished Sedimentary unit I (Geotype 2) lies over the Jurassic ocean crust and is composed of pre-volcanic sediments with thickness of approx. $1 \mathrm{~km}$. Sedimentary unit II (Geotype 3) is composed of sediments from erosion material and giant landslides from surrounding islands and from El Hierro. Its thickness reaches approx. $600 \mathrm{~m}$. Two main geotypes representing majority of the El Hierro structure are represented by solid basalts (Geotype 4) from the lower parts of the volcano covered by basalts with different level of alteration (Geotypes 5a and $5 b$ ). These are overlain by collapse accumulations of the San Andrés Landslide/Las Playas I debris avalanche (Geotype 6). In the subaerial part several lava flows are present (Geotype 7).

\subsection{MODEL PARAMETERS}

Stability modelling has been performed with GeoStudio 2018/GeoSlope, which uses limit equilibrium method for slope stability modelling, namely the Morgenstern-Price approach. The shape of slip surfaces are circular in principle, however the critical slip surface is set to be optimized. For San Andrés DSGSD the Mohr-Coulomb material model (MCMM) was used. The used geotechnical parameters for MCMM for the different geotypes are summarized in Table 1. Geotechnical parameters for the different geotypes were extensively searched in the literature (Hoernle, 1998; Apuani et al., 2005; del Potro and Hürlimann, 2008; Rodríguez-Losada et al., 2009; Stow, 2009; Seisdedos et al., 2012; Ferrer et al., 2014; Cai et al., 2015) and adjusted with regards to El Hierro conditions. Parameters of fresh basalts, lava flows and collapse accumulations come from own laboratory investigation with the assumption of critical state mechanics (Muir Wood, 1990) and extrapolation from relevant rock testing cases (Olejár, 2018; Petružálek, 2018).
Jurassic oceanic crust (142 Ma, van den Bogaard, 2013) in the nearby Gran Canaria Island (210 $\mathrm{km}$ to the east) is composed mostly of pillow lavas (Hoernle, 1998) for this geotype the geotechnical parameters from Cai et al. (2015) were used. For sedimentary unit I data were used from Stow (2009), who analysed saturated sediments influenced by dynamic effects (seismicity and turbidite currents). Post-volcanic sediments of sedimentary unit II are composed of fine clays, sands and gravel but can contain giant blocks reaching tens to hundreds of meters (Weaver et al., 1998; Masson et al., 2002) for that reason this unit has higher unit weight and higher angle of internal friction than sedimentary unit I. El Hierro fresh (non-altered) basalt geotype parameters were used from own testing of fresh basaltic rock taken at the end of approx. $1 \mathrm{~km}$ deep gallery located behind the detachment plane. El Hierro altered basalt geotype was distinguished into three subtypes depending on the level of alteration (fresh basalt, low altered, high altered), which were analysed separately (i.e. separate models were made for each subtype). The geotype parameters of collapse accumulations were set from an analysis of samples taken on the detachment plane. It was assumed, that the material from the detachment plane is formed by finely crushed basalt formed during past slip event(s), which is overlain by more compact material, which might be further cemented under sea level. Subaerial lava flows parameters come from own testing and from the work of Apuani et al. (2005) as recalculated values according to Hoek et al. (2002).

In the main analysis two fully specified slip surfaces and methods of moment and force equilibrium were used in the model (Fig. 3). Slip surface 1 was set along the border between collapse accumulations and altered basalt layer. Slips surface 2 was set deeper (max. $1.2 \mathrm{~km}$ deep) along the border between altered and fresh basalts. In order to investigate the influence of sea level change, three different scenarios were made for each of the slip surfaces: present, minimum and maximum sea level. The maximum and minimum values were set +- $130 \mathrm{~m}$ according to McGuire (1996). As Canary 
Islands are seismically very active and seismicity is considered to play important role in the giant landslide triggering, models with two levels of horizontal seismic loading were also calculated. Horizontal seismic loading was chosen because majority of the earthquakes in the period 2011-2016 are shallow (depth mostly between 7 and $25 \mathrm{~km}$ ) located 10 and more $\mathrm{km}$ to the west of the modelling profile (IGN, 2018; Fig. 1). It has to be noted, that in this analysis we assumed an approach with pseudostatic force using effective parameters. I.e. the stress conditions assume negligible or no change of pore water pressure from the seismic loading. With respect to the decrease of the factor of safety due to increased pore pressure, the results in this study stand for an optimistic estimation of stability conditions under seismic loading.

Firstly, seismic loading with peak ground acceleration PGA $=0.0564 \mathrm{~m} / \mathrm{s}^{2}$ was calculated. This corresponds to an earthquake of $\mathrm{V}$ intensity, which recently happened on El Hierro $(\mathrm{M}=5.1,27.12 .2013$, Blahůt et al., 2018a). Secondly, four times higher loading PGA $=0.22 \mathrm{~m} / \mathrm{s}^{2}$ was used. This corresponds to earthquake of intensity VII. Additionally, two critical seismic loadings, where FS $<1.00$ were calculated for each sea level and slip surface. This resulted in total of 72 models ( 36 for each slip surface including three sea levels, without seismic loading, two types of defined seismic loading and critical seismic loading).

Apart from the manually defined slips surfaces two supplementary models were made using the analysis for high amount of not-predefined slip surfaces ("Grid and Radius Slip Surface Analysis"). This analysis was made for the present sea level and two levels of seismic loading defined above.

\section{RESULTS}

Results for the different analyses are summarised in Tables 2, 3 and 4 for the respective level of basalt alteration. As can be seen from the results neither the sea level change, nor the level of basalt alteration used in the calculation played major role in the resulting factors of safety.

For the slip surface 1 and present sea level the factors of safety varied from $1.264(\mathrm{PGA}=0.22$ equals VII earthquake) to 4.817 (without seismic loading). Similarly, for the slip surface 2 and present sea level the factor of safety varied between 2.212 (PGA=0.22 equals VII earthquake, low-altered basalt) to 7.145 (without seismic loading, fresh basalt).

Results with sea level at $-130 \mathrm{~m}$ from present level showed very similar results. For slip surface 1 the factor of safety varied from 1.275 (PGA=0.22 equals VII earthquake) to 4.728 (no seismic loading. The basalt alteration did not play any role. Slip surface 2 yielded results ranging from 2.11 $(\mathrm{PGA}=0.22$ equals VII earthquake, low-altered basalt) to 6.562 (without seismic loading, fresh basalt).
Higher sea level (+130 m above current level) showed very similar results. For slip surface 1 the results ranged from 1.256 ( $\mathrm{PGA}=0.22$ equals VII earthquake) to 4.883 (no seismic loading). For slip surface 2 the results ranged from 2.115 ( $\mathrm{PGA}=0.22$ equals VII earthquake, low-altered basalt) to 6.733 (no seismic loading, fresh basalt).

The critical seismic loading (when factor of safety reached values lower than 1 ) equals to PGA of $0.29(0.30)$ in case of slip surface 1 . This equals to an earthquake of intensity VII. For slip surface 2, the critical seismic loading equals to PGA of $0.56(0.57)$, which equals to an earthquake of intensity VIII.

Additional stability analysis without predefined slip surfaces yielded interesting results (Fig. 4). In total 26909 slip surfaces were analysed for the two previously mentioned seismic loadings. In case of seismic loading where PGA $=0.0564$ (Fig. 4A) the overall slope seems very stable, with factors of safety reaching more than 1 in the vast majority of the calculated slip surfaces. The only slip surfaces, where factors of safety are lower than 1 are situated right below the sea level. However, the slip surfaces are very shallow (tens of meters) compared to the whole slope. The lowest calculated factor of safety of the optimised slip surface reaches 0.758 .

Analysis, where PGA $=0.22$ is shown on Figure 4B. Apart from the shallow slip surface situated right below the sea level there is large area in the lower part of the volcano slopes and in the sedimentary units I and II, which has very low stability. The lowest calculated factor of safety for the optimised slip surface has only 0.395 .

\section{DISCUSSION AND CONCLUSIONS}

This analysis has shown results of the current stability state of the San Andrés Landslide. The model however, has many limitations and thus must be seen as a first attempt in the stability assessment. The largest limitation arises from the lack of information about the internal structure of the landslide. Despite the fact that the general model is based on close analogy, the lack of borehole data makes the simulation delicate. As it has been shown from the closest boreholes near Gran Canaria (Weaver et al., 1998) the submarine structure is changing rapidly, even in the first tens of meters. This makes the estimation of the geotechnical parameters complicated and generalising them for the whole geotypes might show different results than if better information were available, as stated also by del Potro et al. (2013). Other limitation of the model is that it does not consider the influence of hydrothermal fluid pressures and evolution of dikes. These factors will certainly contribute to lowering of the calculated factors of safety.

Important drawback arises from the fact that the modelling of seismic loading does not consider the increasing pore water pressures resulting from the shaking (i.e. the dynamic forces are in effective 
Table 2 Factors of safety calculated for the Fresh basalt geotype (4).

\begin{tabular}{cccccc}
\hline \multicolumn{5}{c}{ Fresh basalt } \\
\hline \multicolumn{5}{c}{ Sea level -130 m } \\
\hline $\begin{array}{c}\text { No seismic } \\
\text { loading }\end{array}$ & \multicolumn{3}{c}{ PGA $=0.0564$} & \multicolumn{2}{c}{ PGA $=0.22$} \\
\hline SS1 & SS2 & SS1 & SS2 & SS1 & SS2 \\
4.728 & 6.562 & 2.854 & 4.307 & 1.275 & 2.115
\end{tabular}

SS1 critical PGA=0.30 (VII); SS2 critical PGA=0.57 (VIII)

\begin{tabular}{cccccc}
\hline \multicolumn{4}{c}{ Present sea level } \\
\hline \multicolumn{2}{c}{$\begin{array}{c}\text { No seismic } \\
\text { loading }\end{array}$} & \multicolumn{2}{c}{ PGA $=0.0564$} & \multicolumn{2}{c}{ PGA $=0.22$} \\
\hline SS1 & SS2 & SS1 & SS2 & SS1 & SS2 \\
4.817 & 7.145 & 2.902 & 4.714 & 1.264 & 2.117
\end{tabular}

SS1 critical PGA=0.30 (VII); SS2 critical PGA=0.56 (VIII)

\begin{tabular}{|c|c|c|c|c|c|}
\hline \multicolumn{6}{|c|}{ Sea level +130 m } \\
\hline \multicolumn{2}{|c|}{$\begin{array}{l}\text { No seismic } \\
\text { loading }\end{array}$} & \multicolumn{2}{|c|}{$\mathrm{PGA}=0.0564$} & \multicolumn{2}{|c|}{$\mathrm{PGA}=0.22$} \\
\hline SS1 & SS2 & SS1 & $\mathrm{SS} 2$ & SS1 & SS2 \\
\hline 4.883 & 6.733 & 2.872 & 4.366 & 1.256 & 2.119 \\
\hline
\end{tabular}

Table 4 Factors of safety calculated for the Highaltered basalt geotype (5b).

\begin{tabular}{|c|c|c|c|c|c|}
\hline \multicolumn{6}{|c|}{ High-altered basalt } \\
\hline \multicolumn{6}{|c|}{ Sea level $-130 \mathrm{~m}$} \\
\hline \multicolumn{2}{|c|}{$\begin{array}{c}\text { No seismic } \\
\text { loading }\end{array}$} & \multicolumn{2}{|c|}{$\mathrm{PGA}=0.0564$} & \multicolumn{2}{|c|}{$\mathrm{PGA}=0.22$} \\
\hline SS1 & \multirow{2}{*}{$\begin{array}{c}\text { SS2 } \\
6.501\end{array}$} & SS1 & SS2 & SS1 & SS2 \\
\hline 4.728 & & 2.854 & 4.285 & 1.275 & 2.113 \\
\hline \multicolumn{6}{|c|}{$\mathrm{SS} 1$ critical PGA $=0.30(\mathrm{VII}) ; \mathrm{SS} 2$ critical $\mathrm{PGA}=0.56(\mathrm{VIII})$} \\
\hline \multicolumn{6}{|c|}{ Present sea level } \\
\hline \multicolumn{2}{|c|}{$\begin{array}{c}\text { No seismic } \\
\text { loading }\end{array}$} & \multicolumn{2}{|c|}{$\mathrm{PGA}=0.0564$} & \multicolumn{2}{|c|}{$\mathrm{PGA}=0.22$} \\
\hline SS1 & SS2 & $\mathrm{SS} 1$ & $\mathrm{SS} 2$ & SS1 & SS2 \\
\hline 4.817 & 6.591 & 2.864 & 4.316 & 1.264 & 2.115 \\
\hline \multicolumn{6}{|c|}{ SS1 critical PGA $=0.30(\mathrm{VII}) ; \mathrm{SS} 2$ critical $\mathrm{PGA}=0.56$ (VIII) } \\
\hline \multicolumn{6}{|c|}{ Sea level $+130 \mathrm{~m}$} \\
\hline \multicolumn{2}{|c|}{$\begin{array}{l}\text { No seismic } \\
\text { loading }\end{array}$} & \multicolumn{2}{|c|}{$\mathrm{PGA}=0.0564$} & \multicolumn{2}{|c|}{$\mathrm{PGA}=0.22$} \\
\hline SS1 & SS2 & $\mathrm{SS} 1$ & $\mathrm{SS} 2$ & SS1 & $\mathrm{SS} 2$ \\
\hline 4.883 & 6.664 & 2.872 & 4.342 & 1.256 & 2.118 \\
\hline
\end{tabular}

Table 3 Factors of safety calculated for the Lowaltered basalt geotype (5a).

\begin{tabular}{lccccc}
\hline \multicolumn{5}{c}{ Low-altered basalt } \\
\hline \multicolumn{5}{c}{ Sea level $\mathbf{- 1 3 0}$ m } \\
\hline \multicolumn{3}{c}{$\begin{array}{c}\text { No seismic } \\
\text { loading }\end{array}$} & \multicolumn{2}{c}{ PGA $=0.0564$} & \multicolumn{2}{c}{ PGA $=0.22$} \\
\hline SS1 & SS2 & SS1 & SS2 & SS1 & SS2 \\
4.728 & 6.411 & 2.854 & 4.252 & 1.275 & 2.11
\end{tabular}

SS1 critical PGA=0.30 (VII); SS2 critical PGA=0.56 (VIII)

\begin{tabular}{cccccc}
\hline \multicolumn{5}{c}{ Present sea level } \\
\hline \multicolumn{2}{c}{$\begin{array}{c}\text { No seismic } \\
\text { loading }\end{array}$} & \multicolumn{2}{c}{ PGA $=0.0564$} & \multicolumn{2}{c}{ PGA $=0.22$} \\
\hline SS1 & SS2 & SS1 & SS2 & SS1 & SS2 \\
4.817 & 6.495 & 2.864 & 4.282 & 1.264 & 2.112
\end{tabular}

SS1 critical PGA=0.30 (VII); SS2 critical PGA=0.56 (VIII)

\begin{tabular}{|c|c|c|c|c|c|}
\hline \multicolumn{6}{|c|}{ Sea level +130 m } \\
\hline \multicolumn{2}{|c|}{$\begin{array}{l}\text { No seismic } \\
\text { loading }\end{array}$} & \multicolumn{2}{|c|}{$\mathrm{PGA}=0.0564$} & \multicolumn{2}{|c|}{$\mathrm{PGA}=0.22$} \\
\hline $\mathrm{SS} 1$ & $\mathrm{SS} 2$ & SS1 & $\mathrm{SS} 2$ & SS1 & $\mathrm{SS} 2$ \\
\hline 4.883 & 6.562 & 2.872 & 4.305 & 1.256 & 2.115 \\
\hline
\end{tabular}

state). This was not considered because there are not any data about the filtration coefficients. It might be possible that the effect of the pore water pressure changes has significant influence than changes in seismic loading. Del Potro et al. (2013) made parametrical study on the influence of changes of pore water pressures and changes in PGA on Teide volcano on Tenerife. His results show that seismic loading influences more the deeper slip surfaces and that the effect of pore water pressure changes is proportional to the seismic loading. Del Potro et al. (2013) also state that in case of higher pore water pressures the increasing seismic loading has not important effect on the overall stability. Thus, the existing stability calculations of San Andrés Landslide have to be considered as the highest possible for the respective levels of seismic loading.

Despite already mentioned limitations of the analysis, the results are in very good agreement with the findings of Apuani et al. (2005) from Stromboli volcano. They concluded that the volcano slope is stable without external factors and that tectonic seismicity alone does not destabilize the slope. They state however, that magma pressure and dikes can represent a destabilizing factor. Similarly, the results of Dondin et al. (2017) at Kick-'em-Jenny submarine volcano showed overall stability of the volcano. They did not test the influence of hydrothermal system 

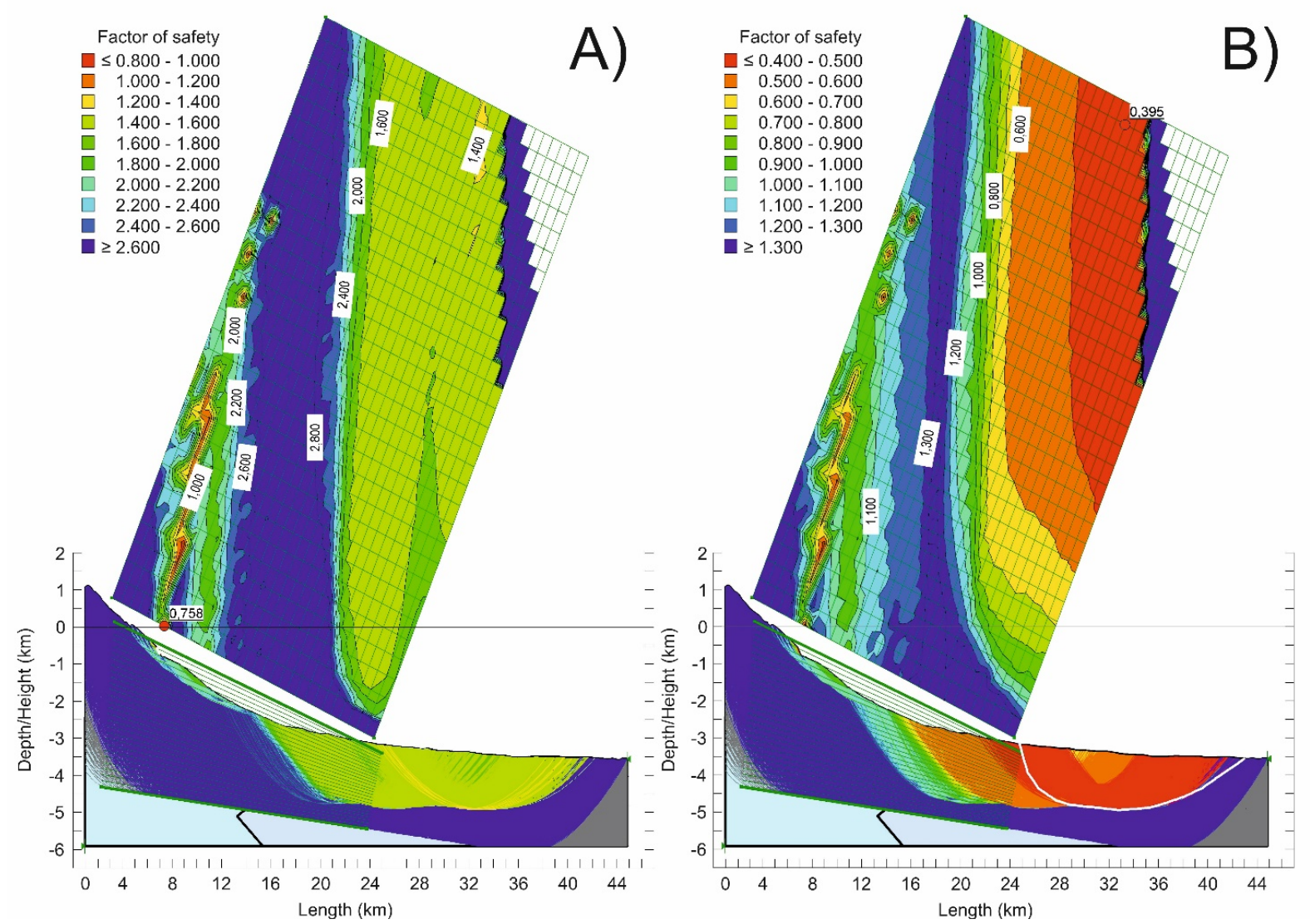

Fig. 4 Results of the analysis for non-defined slip surface. A) for PGA $=0.0564$; B) for PGA $=0.22$. Please note the different factor of safety scale on A and B. The profile runs from WNW to ESE as shown on Figure 1.

fluid pressurization. They argue however, that this is one of the major factors promoting flank instability. Harnett et al. (2018) showed that large deep-seated failures occur when the volcanic dome is exposed to internal overpressures. Borselli et al. (2011) implemented a fluid pressure function in their analysis and calculated factors of safety between 0.997 and 1.700 for Colima volcano in Mexico. Del Potro et al. (2013) also concluded that the Teide volcano is stable with factors of safety between 1.3 1.8 and Ferrer et al. (2014) reached similar results for Teide (FS > 1.5) and La Palma (FS > 1.8) volcanoes.

The results of the critical seismic loading for slips surface 1 and 2 yielded PGA of intensities VII and VIII respectively. According to Gonzáles de Vallejo et al. (2006) these intensities are not uncommon in the area of Canary Islands. Moreover, the strong seismicity is usually accompanied with volcanic activity, which might further destabilise the volcanic flanks. The influence of sea level did not show any influence on the calculated stability. This might be due to the fact that the maximum considered sea level change $(+-130 \mathrm{~m})$ is less than $10 \%$ of the more than $3000 \mathrm{~m}$ high water level in the whole model. This result also questions the findings of Carracedo et al. (1999) and Ablay and Hürlimann (2000) who connect the past large flank collapses with lower sea levels during glacial periods.
It can be concluded, that according to the numerical modelling performed, the San Andrés Landslide is currently stable and the reactivation might be a result of an earthquake with minimum VII intensity. However, this hypothesis is speculative to some point as there are many uncertainties connected with setting the strength parameters. In addition, the detailed determination of slip surface portions with different sliding velocities is not possible as the geology in greater depths is essentially unknown.

On the other hand, the installed monitoring system shows that the sliding masses are very sensitive to earthquake events. The slope deformation has currently an evident slow creep movement as directly observed by Klimeš et al. (2016) and Blahůt et al. $(2017,2018 \mathrm{a})$. Even in seismically calm periods this creep might be induced by the unconsolidated sea sediments. These are most susceptible to seismic loading and might liquefy during earthquakes. This might cause softening of the toe of the slope and consequent fast slip of the more coherent volcanic rocks upslope.

When assuming the fact that the observed creep movements indicate the lack of shear resistance of the whole sliding system or of a certain portion of the slip surface, then on the basis of final results, we believe that the process of sliding on San Andrés Landslide slowly continues. 


\section{ACKNOWLEDGEMENTS}

We thank two anonymous reviewers for their comments, which improved the clarity of this paper. This study was supported by the Czech Science Foundation (GJ16-12227Y) and the long-term conceptual development research organisation of the Institute of Rock Structure and Mechanics (RVO: 67985891). Josef Rott gratefully thanks to the financial support from the project Centre for Geosphere Dynamic (UNCE/SCI/006). Our study was also partly supported by the Institute of Geology of the Czech Academy of Sciences (RVO: 67985831).

\section{REFERENCES}

Ablay, G. and Hürlimann, M.: 2000, Evolution of the northern flank of Tenerife by recurrent giant landslides. J. Volcanol. Geotherm. Res., 103, 1-4, 135-159. DOI: 10.1016/S0377-0273(00)00220-1

Agliardi, F., Crosta, G. and Zanchi, A.: 2001, Structural constraints on deep seated slope deformation kinematics. Eng. Geol., 59, 83-102. DOI: 10.1016/S0013-7952(00)00066-1

Apuani, T., Corazzato, C., Cancelli, A. and Tibaldi, A.: 2005, Stability of a collapsing volcano (Stromboli, Italy): Limit equilibrium analysis and numerical modelling. J. Volcanol. Geotherm. Res., 144, 191210. DOI: $10.1016 /$ j.jvolgeores.2004.11.028

Apuani, T. and Corazzato, C.: 2009, Numerical model of the Stromboli volcano (Italy) including the effect of magma pressure in the dyke system. Rock Mech. Rock Eng., 42, 1, 53-72. DOI: $10.1007 / \mathrm{s} 00603-008-0163-1$

Becerril, L., Ubide, T., Sudo, M., Martí, J., Galindo, I., Galé, C., Morales, J., Yepes, J. and Lago, M.: 2016a, Geochronological constraints on the evolution of El Hierro (Canary Islands). J. Afr. Earth Sci., 113, 8894. DOI: 10.1016/j.jafrearsci.2015.10.012

Becerril, L., Galve, J., Morales, J., Romero, C., Sánchez, N., Martí, J. and Galindo, I.: 2016b, Volcanostructure of El Hierro (Canary Islands). J. Maps, 12, 43-52. DOI: 10.1080/17445647.2016.1157767

Benito-Saz, M., Parks, M., Sigmundsson, F., Hooper, A. and García-Cañada, L.: 2017, Repeated magmatic intrusions at El Hierro Island following the 20112012 submarine eruption. J. Volcanol. Geotherm. Res., 344, 79-91.

DOI: 10.1016/j.jvolgeores.2017.01.020

Borselli, L., Capra, L., Sarocchi, D. and De la Cruz-Reyna, S.: 2011, Flank collapse scenarios at Volcán de Colima, Mexico: A relative instability analysis. J. Volcanol. Geotherm. Res., 208, 51-65.

DOI: 10.1016/j.jvolgeores.2011.08.004

Blahůt, J., Rowberry, M., Balek, J., Klimeš, J., Baroň, I., Meletlidis, S. and Martí, X.: 2017, Monitoring giant landslide detachment planes in the era of big data analytics. In: Mikoš, M., Arbanas, Ž., Yin, Y. and Sassa, K. (Eds.): Advancing Culture of Living with Landslides, Volume 3. Springer, Cham, 333-340. DOI: $10.1007 / 978-3-319-53487-938$

Blahůt, J., Baroň, I., Sokol', L., Meletlidis, S., Klimeš, J., Rowberry, M., Melichar, R., García-Cañada, L. and Martí, X.: 2018a, Large landslide stress states calculated during extreme climatic and tectonic events on El Hierro, Canary Islands. Landslides, 15, 9, 1801-1814. DOI: 10.1007/s10346-018-0993-1
Blahůt, J., Klimeš, J., Rowberry, M. and Kusák, M.: 2018b, Database of giant landslides on volcanic islands - first results from the Atlantic Ocean. Landslides, 15, 823827. DOI: 10.1007/s10346-018-0967-3

Blahůt, J., Balek, J., Klimeš, J., Rowberry, M., Kusák, M. and Kalina, J.: 2019, A comprehensive global database of giant landslides on volcanic islands. Landslides, 16, 2045-2052. DOI: $10.1007 / \mathrm{s} 10346-019-01275-8$

Blahůt, J., Mitrovic-Woodell, I., Baroň, I., René, M., Rowberry, M., Blard, P.-H., Hartvich, F. and Meletlidis, S.: 2020, Volcanic edifice slip events recorded on the fault plane of the San Andrés Landslide, El Hierro, Canary Islands. Tectonophysics, 776, 228317. DOI: $10.1016 /$ j.tecto.2019.228317

Cai, M., Huusgard, P. and Caycedo, A.: 2015, Diamondimpregnated drillbit performance in the lower basalt series offshore the Faroe Islands. A case study based on basalt outcrop testing. Conference paper SPE175880-MS, Society of Petroleum Engineers, $22 \mathrm{pp}$. DOI: $10.2118 / 175880-\mathrm{MS}$

Carracedo, J.C., Day, S., Guillou, H. and Pérez Torrado, F.: 1999, Giant quaternary landslides in the evolution of La Palma and El Hierro, Canary Islands. J. Volcanol. Geotherm. Res., 94, 169-190. DOI: 10.1016/S0377-0273(99)00102-X

Carracedo, J.C., Rodríguez Badiola, E., Guillou, H., de la Nuez, H., Pérez Torrado, F.: 2001, Geology and volcanology of the western Canaries: La Palma and El Hierro. Estudios Geológicos, 57, 5, 171-295.

Carracedo, J.-C. and Troll, V.: 2016, The Geology of Canary Islands. Elsevier, Amsterdam, $636 \mathrm{pp}$. DOI: 10.1016/B978-0-12-809663-5.00002

Cecchi, E., van Wyk de Vries, B. and Lavest, J.-M.: 2005, Flank spreading and collapse of weak-cored volcanoes. J. Volcanol. Geotherm. Res., 67, 1, 72-91. DOI: $10.1007 / \mathrm{s} 00445-004-0369-3$

Day, S., Carracedo, J.-C. and Guillou, H.: 1997, Age and geometry of an aborted rift flank collapse: the San Andres fault system, El Hierro, Canary Islands. Geol. Mag., 134, 523-537.

DOI: $10.1017 / \mathrm{S} 0016756897007243$

del Potro, R. and Hürlimann, M.: 2008, Geotechnical classification and characterisation of materials for stability analyses of large volcanic slopes. Eng. Geol., 98, 1-17. DOI: 10.1016/j.enggeo.2007.11.007

del Potro, R., Hürlimann, M., Pinkerton, H.: 2013, Modelling flank instabilities on stratovolcanoes: Parameter sensitivity and stability analyses of Teide, Tenerife. J. Volcanol. Geotherm. Res., 256, 50-60. DOI: 10.1016/j.jvolgeores.2013.02.003

Dondin, F.J.-Y., Heap, M.J., Robertson, R.E.A., Dorville, J.-F.M. and Carrey, S.: 2017, Flank stability assessment at Kick-'em-Jenny submarine volcano (Grenada, Lesser Antilles): a multidisciplinary approach using experiments and modelling. Bull. Volcanol., 79, 5. DOI: 10.1007/s00445-016-1090-8

Donnadieu, F., Merle, O. and Besson, J.C.: 2001, Volcanic edifice stability during cryptodome intrusion. Bull. Volcanol., 63, 61-72. DOI: 10.1007/s004450000122

Duffield, W.: 1975, Structure and origin of the Koae Fault System, Kilauea Volcano, Hawaii. United States Geological Survey, Professional Paper 856, 12 pp.

Ellsworth, D. and Voight, B.: 1995, Dike intrusion as a trigger for large earthquakes and the failure of volcano flanks. J. Geophys. Res., 100, 6005-6024. DOI: $10.1029 / 94 J B 02884$ 
Ferrer, M., Gonzáles de Vallejo, L., Gonzáles, S. and Jimenéz, E.: 2014, Stability and failure mechanisms of large land-slides in the volcanic islands flanks of the Canary Islands. In: Lollino, G., Giordan, D., Crosta, G.B., Corominas, J., Azzam, R., Wasowski, J. and Sciarra, N. (Eds.): Engineering Geology for Society and territory - Volume 2 Landslide Processes. Springer, Cham, 915-919. DOI: 10.1007/978-3-319-09057-3 158

Gee, M.J., Martin, J.R., Watts, A.B., Masson, D.G., and Mitchell, N.C.: 2001, Landslides and the evolution of El Hierro in the Canary Islands. Mar. Geol., 177, 271-293. DOI: 10.1016/S0025-3227(01)00153-0

Gómez Sainz de Aja, J., Klein, E., Ruiz García, M., Balcells Herrera, R., Del Pozo, M., Galindo, E. and La Moneda, E.: 2010, Mapa Geológico de España Escala 1:25 000. Valverde (Isla de El Hierro). Hoja $\mathrm{N}^{\circ}$ 1105-II, Memoria, 98 p. Obtained from: http://info.igme.es/cartografia/datos/magna50/memori as/MMagna1 105IIN.pdf

Gonzáles de Vallejo, L.I., García-Mayordomo, J. and Insua, J.M.: 2006, Probabilistic seismic-hazard assessment of the Canary Islands. Bull. Seis. Soc. Am., 96, 6, 2040-2049. DOI: 10.1785/0120050139

Guillou, H., Carracedo, J.-C., Pérez Torrado, F. and Rodríguez Badiola, E.: 1996, K-Ar ages and magnetic stratigraphy of a hotspot-induced, fast grown oceanic island: El Hierro, Canary Islands. J. Volcanol. Geotherm. Res., 73, 141-155.

DOI: 10.1016/0377-0273(96)00021-2

Harnett, C.E., Thomas, M.E., Purvance, M.D. and Neuberg, J.: 2018, Using a discrete element approach to model lava dome emplacement and collapse. J. Volcanol. Geotherm. Res., 359, 68-77. DOI: 10.1016/j.jvolgeores.2018.06.017

Hildenbrand, A., Marques, F., Catalao, J., Catita, C. and Costa, A.: 2012, Large scale active slump of the southeastern flank of Pico Island, Azores. Geology, 40, 939-942. DOI: 10.1130/G33303.1

Hoek, E., Carranza-Torres, C.T. and Corkum, B.: 2002, Hoek-Brown failure criterion-2002 edition. In: Hammah, R., Bawden, W., Curran, J. and Telesnicki, M. (Eds.): Proceedings of the Fifth North American Rock Mechanics Symposium (NARMS-TAC), University of Toronto Press, Toronto, 267-273.

Hoernle, K.: 1998, Geochemistry of Jurassic Oceanic Crust beneath Gran Canaria (Canary Islands): Implications for crustal recycling and assimilation. J. Petrol., 39, 5, 859-880. DOI: $10.1093 /$ petroj/39.5.859

IGN: 2018, El Hierro seismology - localisation of events, Instituto Geográfico Nacional, Spain. Available at: http://www.ign.es/web/resources/volcanologia/SIS/ht ml/HI_SIS_eventos.html (Accessed on 23/9/2018)

IHM: 2016, Bathymetric data of the Canary Islands. Insituto Hidrográfico de la Marina, Cuartel General de la Armada, Spain Obtained from: http://portal.emodnetbathymetry.eu

Iverson, R.: 1995, Can magma-injection and groundwater forces cause massive landslides on Hawaiian volcanoes? J. Volcanol. Geotherm. Res., 66, 295308. DOI: 10.1016/0377-0273(94)00064-N

Klimeš, J., Yepes, J., Becerril, L., Kusák, M., Galindo, I. and Blahut, J.: 2016, Development and recent activity of the San Andrés landslide on El Hierro, Canary Islands, Spain. Geomorphology, 261, 119-131. DOI: 10.1016/j.geomorph.2016.02.018
Krastel, S., Schmincke, H.-U., Jacobs, C.L., Rihm, R., Le Bas, T.P. and Alibés, B.: 2001, Submarine landslides around the Canary Islands. J. Geophys. Res.: Solid Earth, 106, 83, 3977-3997.

DOI: $10.1029 / 2000 J B 900413$

León, R., Somoza, L., Urgeles, R., Medialdea, T., Ferrer, M., Biain, A., García-Crespo, J., Mediato, J., Galindo, I., Yepes, J., González, F. and GimenezMoreno, J.: 2017, Multi-event oceanic island landslides: new onshore-offshore insights from El Hierro Island, Canary archipelago. Mar. Geol., 393, 156-175. DOI: 10.1016/j.margeo.2016.07.001

Longpré, M., Chadwick, J., Wijbrans, J. and Iping, R.: 2011, Age of the El Golfo debris avalanche, El Hierro (Canary Islands): new constraints from laser and furnace $40 \mathrm{Ar} / 39 \mathrm{Ar}$ dating. J. Volcanol. Geotherm. Res., 203, 76-80.

DOI: $10.1016 /$ j.jvolgeores.2011.04.002

López, C., Blanco, M., Abella, R., Brenes, B., Cabrera Rodríguez, V., Casas, B., Domínguez Cerdeña, I., Felpeto, A., Fernández de Villalta, M., Del Fresno, C., et al.: 2012, Monitoring the volcanic unrest of El Hierro (Canary Islands) before the onset of the 20112012 submarine eruption. Geophys. Res. Lett., 39, L13303. DOI: 10.1029/2012GL051846

Masson, D.: 1996, Catastrophic collapse of the volcanic island of Hierro $15 \mathrm{ka}$ ago and the history of landslides in the Canary Islands. Geology, 24, 231234.

DOI: 10.1130/0091-7613(1996)024<0231:CCOTVI >2.3.CO;2

Masson, D., Watts, A.B., Gee, M.J., Urgeles, R., Mitchell, N., Le Bas, T. and Canals, M.: 2002, Slope failures on the flanks of the western Canary Islands. EarthSci. Rev., 57, 1-35. DOI: $10.1016 / \mathrm{S} 0012-8252(01) 00069-1$

Meletlidis, S., Di Roberto, A., Domínguez Cerdeña, I., Pompilio, M., García-Cañada, L., Bertagnini, A., Benito-Saz, M., Del Carlo, P. and Sainz-Maza Aparicio, S.: 2015, New insight into the 2011-2012 unrest and eruption of El Hierro Island (Canary Islands) based on integrated geophysical, geodetical, and petrological data. Ann. Geophys. Italy, 58, S0546. DOI: $10.4401 /$ ag-6754

McGuire, W.J.: 1996, Volcano instability: a review of contemporary themes. Volcano Instability on the Earth and Other Planets, 110, 1-23. DOI: $10.1144 /$ GSL.SP.1996.110.01.01

MDT05: 2015, Modelo Digital del Terreno de España. Sheet PNOA-MDT05-REGCAN95-HU28-11051108-LID.ASC. Obtained from http://centrodedescargas.cnig.es/CentroDescargas.

Moscardelli, L. and Wood, L.: 2008, New classification system for mass transport complexes in offshore Trinidad. Basin Res., 20, 73-98. DOI: $10.1111 / \mathrm{j} .1365-2117.2007 .00340 . \mathrm{x}$

Moon, V., Bradshaw, J. and de Lange, W.: 2009, Geomorphic development of White Island Volcano based on slope stability modelling. Eng. Geol., 104, 16-30. DOI: 10.1016/j.enggeo.2008.08.003

Muir Wood, D.: 1990, Soil behaviour and critical state soil mechanics. Cambridge University Press, Cambridge, 488 pp. DOI: $10.1017 / \mathrm{CBO} 9781139878272$

Olejár, F.: 2018, Stability of volcanic islands in relation to giant landslides on the example of El Hierro Island, Canary Islands. Diploma thesis, Charles University in Prague, Faculty of Science, Institute of 
Hydrogeology, Engineering Geology and Applied Geophysics, 87 pp., (in Slovak).

Petružálek, M.: 2018, Laboratory tests of rocks from El Hierro, final report. Unpublished, Geological Institute of the Czech Academy of Sciences, 13 pp., (in Czech).

Reid, M.E., Sisson, T.W. and Brien, D.L.: 2001, Volcano collapse promoted by hydrothermal alteration and edifice shape, Mount Rainier, Washington. Geology, 29, 9, 779-782.

DOI: 10.1130/0091-7613(2001)029<0779:VCPBHA>2.0.CO;2

Rodríguez-Losada, J.A., Hernández-Gutiérrez, L.E., Olalla, C., Perucho, A., Serrano, A. and Eff-Darwich, A.: 2009, Geomechanical parameters of intact rocks and rock masses from the Canary Islands: Implications of their flank stability. J. Volcanol. Geotherm. Res., 182, 67-75. DOI: 10.1016/j.jvolgeores.2009.01.032

Seisdedos, J., Ferrer, M. and Gonzáles-Vallejo, L.I.: 2012, Geological and geomechanical models of the prelandslide volcanic edifice of Güímar and La Orotava mega-landslides (Tenerife). J. Volcanol. Geotherm. Res., 239-240, 92-110. DOI: 10.1016/j.jvolgeores.2012.06.013

Schmincke, H.-U. and Sumita, M.: 2010, Geological evolution of the Canary Islands: a young volcanic archipelago adjacent to the old African continent. Görres-Verlag, Koblenz, 200 pp.

Siebert, L.: 2002, Landslides resulting from structural failure of volcanoes. In: Evans, S.G. and DeGraff, J.V. (Eds.): Catastrophic Landslides: Effects, Occurrence, and Mechanisms: Boulder, Colorado. Geological Society of America Reviews in Engineering Geology, XV, 209-235. DOI: 10.1130/REG15-p209

Sorriso-Valvo, M., Gullà, G., Antronico, L., Tansi, C. and Amelio, M.: 1999, Mass movement, geologic structure, and morphologic evolution of the PizzottoGreci Slope (Calabria, Italy). Geomorphology, 30, 147-163. DOI: 10.1016/S0169-555X(99)00051-3

Stow, D.A.V.: 2009, Deep-Water Turbidite Systems, The International Association of Sedimentologists, Gent, 480 pp. DOI: $10.1002 / 9781444304473$

Troll, V. and Carracedo, J.C.: 2016, The geology of El Hierro. In: Carracedo, J.C. and Troll, V. (Eds.): The geology of Canary Islands. Elsevier, Amsterdam, pp 43-99. DOI: 10.1016/B978-0-12-809663-5.00002-5

Urgeles, R., Canals, M., Baraza, J. and Alonso, B.: 1996, The submarine El Golfo debris avalanche and the Canary debris flow, west Hierro Island: the last major slides in the Canary Archipelago. Geogaceta, 20, 390-393.

Urgeles, R., Canals, M., Baraza, J., Alonso, B. and Masson, D.: 1997, The most recent megalandslides on the Canary Islands: the El Golfo debris avalanche and the Canary debris flow, west El Hierro Island. J. Geophys. Res., Solid Earth, 102, 20305-20323.

DOI: 10.1029/97JB00649
Urgeles, R., Canals, M., Baraza, J., and Alonso, B.: 1998, Seismostratigraphy of the western flanks of El Hierro and La Palma (Canary Islands): a record of Canary Islands volcanism. Mar. Geol., 146, 225-241. DOI: 10.1016/S0025-3227(97)00130-8

van den Bogaard, P.: 2013, The origin of the Canary Island Seamount Province new ages of old seamounts. Sci. Rep., 3, 2107. DOI: 10.1038/srep02107

Van Wyk de Vries, B. and Francis, P.W.: 1997, Catastrophic collapse at stratovolcanoes induced by gradual volcano spreading. Nature, 387, 387-390. DOI: $10.1038 / 387387 \mathrm{a} 0$

Voight, B., Janda, R.H., Glicken, H.X. and Douglass, P.M.: 1983, Nature and mechanics of the Mount St. Helens rockslide-avalanche of 18 May 1980. Géotechnique, 33, 3, 243-273. DOI: 10.1680/geot.1983.33.3.243

Watt, S.F.L.: 2019, The evolution of volcanic systems following sector collapse. J. Volcanol. Geotherm. Res., 384, 280-303. DOI: 10.1016/j.jvolgeores.2019.05.012

Weaver, P.P.E., Schmincke, H.-U., Firth, J.V. and Duffield., W.: 1998, Proceedings of the Ocean Drilling Program, Scientific Reults, Vol. 157, College Station, TX (Ocean Drilling Program). DOI: 10.2973/odp.proc.sr.157.1998 